\title{
Key Dimensions of Personal Innovativeness
}

\author{
by Walley, K., Goodall, S., Humphries, A., Huntington, \\ J., White, D. and Asson, T.
}

Copyright, Publisher and Additional Information: This is the author accepted manuscript. The final published version (version of record) is available online via Inderscience.

Please refer to any applicable terms of use of the publisher.

DOI: : http://dx.doi.org/10.1504/IJBIR.2017.10001672 


\title{
Key Dimensions of Personal Innovativeness
}

\author{
by \\ Keith Walley, Sophie Goodall, Andrea Humphries, Jim Huntington, \\ David White and Tony Asson
}

\section{Author Contact Details}

Keith Walley (Corresponding author), International Programmes Manager, Harper Adams University, Newport, Shropshire TF10 8NB, United Kingdom. Telephone: +44 (0)1952 820280. Email: kwalley@harper-adams.ac.uk

Sophie Goodall, Knowledge Transfer Partnership (KTP) Associate, Harper Adams University, Newport, Shropshire TF10 8NB, United Kingdom. Telephone: +44 (0)1952 820280. Email: sgoodall@harper-adams.ac.uk

Andrea Humphries, Senior Lecturer in Sustainable Technologies, Department of Crop and Environment Sciences, Harper Adams University, Newport, Shropshire TF10 8NB, United Kingdom. Telephone: +44 (0)1952 820280. Email: ahumphries@harper-adams.ac.uk

Jim Huntington, Senior Lecturer in Animal Systems, Department of Animal Production, Welfare and Veterinary Sciences, Harper Adams University, Newport, Shropshire TF10 8NB, United Kingdom. Telephone: +44 (0)1952 820280. Email: jhuntington@harperadams.ac.uk

David White, Senior Lecturer in Engineering, Department of Engineering, Harper Adams University, Newport, Shropshire TF10 8NB, United Kingdom. Telephone: +44 (0)1952 820280. Email: dwhite@harper-adams.ac.uk

Tony Asson, Senior Lecturer in Farm and Business Management, Department of Land, Farm and Agribusiness Management, Harper Adams University, Newport, Shropshire TF10 8NB, United Kingdom. Telephone: +44 (0)1952 820280. Email: tasson@harper-adams.ac.uk 


\begin{abstract}
The purpose of this paper is to provide insight into the concept of Personal Innovativeness through an application of the Ettlie and O'Keefe (1982) Innovativeness Scale. A mixed-mode approach to data collection involving online and postal surveying was used to obtain responses from 404 practicing UK managers. Although the work has a number of limitations relating to the Personal Innovativeness scale employed and difficulties associated with comparative analysis of the results, the findings are statistically significant and appear to have face value. The most important finding from this study is the identification of five key dimensions of Personal Innovativeness which suggests that the concept is fragmenting and becoming more complex. The paper concludes by considering the implications of the findings in terms of recruitment of managers, their education and training, the design of reward packages, and the allocation of resources.
\end{abstract}

\title{
Key words
}

Personal innovativeness, innovativeness scales, innovativeness.

\section{$1 \quad$ Introduction}

Innovation is a complex concept (Roehrich, 2004; Trott, 2012) that is difficult to define (Tellis et al, 2009), however, for the purposes of this paper it will be taken to be “...the management of all the activities involved in the process of idea generation, technology development, manufacturing and marketing of a new, or improved, product or service" (adapted from Trott, 2012, p15). Innovation is an essential activity if an organisation is to adapt and evolve in response to change in its business and competitive environments (Trott, 2012). Indeed, Erikson et al (2008), Priyadharshini et al (2015), Schumpeter (1943), and Steenkamp et al (1999) argue that it is essential for organisational evolution, growth and profitability.

The subject of innovation provides a rich setting for researchers and, as a consequence, the literature on innovation is extensive. Indeed, a recent search of the Business Source Complete database using “innovation" in a key word search produced 250,003 hits. This literature deals with all manner of matters associated with innovation but one subject that has been of interest over many years is an individual's disposition to innovate or Personal Innovativeness and it is this that is the focus of this paper.

The paper outlines the methodology used to collect data regarding Personal Innovativeness as well as presenting and interpreting the output from an innovativeness scale. A section is devoted to explaining a factor analysis which was conducted for the purpose of trying to identify the key dimensions of Personal Innovativeness and the paper ends with a summary and conclusions section. To begin, however, it is useful to consider the nature of Personal Innovativeness in more detail. 
According to Ettlie and O'Keefe (1982) there is "widespread evidence” of a relationship between an individual's attitudes or values and their innovative behaviour. Indeed, as Rothwell

(1994, p2) states "..at the very heart of the successful innovation process were "key individuals'... with a strong commitment to innovation". Further, while research into the relationship between individuals and innovation extends back to the late 1960's and early 1970's (eg Nabseth and Ray, 1974; Rokeach, 1967) the subject remains a popular focus for projects today with journals still regularly reporting the results of research into the nature of the relationship (eg Hidayanto et al, 2015; Tan and Sie, 2015; Thakur and Srivastava, 2015).

The basis for research into the relationship between individuals and innovation is the tendency for people to react differently when presented with innovations. Some appear much more willing to take a risk and to adopt the innovation much more readily than others who are suspicious and risk-adverse ( $\mathrm{Yi}$ et al, 2006). This propensity is persistent and enduring across time, cultures and innovation domain types (Goldsmith, 1991; Hurt et al, 1977; Midgley and Dowling, 1978; Moore, 1999; Rogers, 1995; and Yi et al, 2006) and as a consequence it is the basis for much of modern innovation adoption theory (Rogers, 1995) and many studies (eg Fagan et al, 2012; Im et al, 2003; Jackson et al, 2013; Yang et al, 2007; Yi et al, 2006) have supported the existence of a relationship between innovativeness and innovation.

Innovativeness was initially operationalised in terms of "time of adoption" but this approach was not seen as particularly useful (Agarwal and Prasad, 1998) because it is too narrow, does not allow inter-study comparison, and lacks reliability and validity metrics (Midgley and Dowling, 1978). Instead, most contemporary authors now assume that it is a latent personality trait (Roehrich, 2004) that is derived from cognitive and / or sensory motivations (Venkatraman, 1991).

The propensity to innovate has been referred to as innovativeness (Midgley and Dowling, 1978; Steenkamp et al, 1999; and Venkatraman, 1991), innovative predisposition (Midgley and Dowling, 1993), innate innovativeness (Hirschman, 1980; Im et al, 2003; Roehrich, 2004; Yi et al, 2006) and Personal Innovativeness (Agarwal and Prasad, 1998; Lin, 2006; Rogers, 1995). According to Agarwal and Prasad (1998, p206), “...personal innovativeness as a construct that is important to the study of individual behaviour toward innovations has had a long-standing tradition in innovation diffusion research...”. As a consequence, this paper will use the term Personal Innovativeness and adopt the definition proposed by Rogers (1995, p252) which is "the degree to which an individual or other unit of adoption is relatively early in adopting new ideas".

When considering Personal Innovativeness Midgley and Dowling (1978) believe that it is important to distinguish between propensity to innovative and actual Personal Innovativeness. This is because while an individual's propensity to innovative might be high, their opportunities to innovate may be limited and their revealed or actual Personal Innovativeness might be low. This is because of various generic intervening variables including innovation characteristics (Steenkamp et al, 1999), marketing factors (Steenkamp et al, 1999), and social interactions (Midgley and Dowling, 1978). In the work setting the intervening factors may 
also include aspects of the job being addressed, the team, and the organisation (Hormiga et al, 2013).

In addition to acknowledging a difference between propensity to innovative and actual Personal Innovativeness it is also useful to distinguish between general Personal Innovativeness and domain specific Personal Innovativeness (Agarwal and Prasad, 1998). As Trot (2012, p11) reminds us "Within organisations it is individuals who define problems, have ideas and perform creative linkages and associations that lead to inventions..." and “... within organisations it is individuals in the role of managers who decide what activities should be undertaken, the amount of resources to be deployed and how they should be carried out". As such, individual employees and especially managers (Augusto et al, 2014; Burdon et al, 2013; Dershin, 2010; Dubey et al, 2015; Munoz-Doyague and Nieto, 2012) are often faced with numerous and varied innovatory contexts and knowledge concerning their general Personal Innovativeness provides valuable insight concerning their likely behaviour. On the other hand, however, general Personal Innovativeness may not have a particularly strong effect on the specific behaviours exhibited in a specific situation or domain (Venkatraman, 1991) and Goldsmith and Hofacker (1991) claim that domain specific scales offer better predictive power than generic scales.

Over the last 40 years numerous researchers have sought to measure Personal Innovativeness (sometimes in the form of innovativeness) using various scales. It is apparent that some of the scales have sought to measure Personal Innovativeness as a generic construct (eg Ettlie and O’Keefe, 1982; Goldsmith, 1991; Hurt et al, 1977; Kirton, 1976; Kocak and Onen, 2012; Pallister and Foxall, 1998) while others have sought to measure Personal Innovativeness as a domain specific construct. These specific domains include entrepreneurship (Gibson and Gibson, 2011), personality (Jackson, 1976), propensity to change (Hage and Dewar, 1973), innovative purchasing behaviour (Leavitt and Walton, 1975), consumer innovativeness and decision making (Goldsmith and Hofacker, 1991; Goldsmith et al, 1995; Ostlund, 1974), mobile commerce (Kourouthanassis et al, 2014; Lu, 2014; Roca et al, 2010; Thakur and Srivastava, 2015), exploratory behaviour (Baumgartner and Steenkamp, 1996; Raju, 1980), consumers eco-innovation (Jansson, 2011), internet banking (Gounaris and Koritos, 2008; Hidayanto et al, 2015), Information Technology (Agarwal and Prasad, 1998; Jackson et al, 2013; Tan and Sie, 2015; Yi et al, 2006), virtual reality simulations (Fagan et al, 2012), webcasting adoption (Lin, 2006), employee level (Hormiga et al, 2013), social media marketing (Pentina et al, 2014), and mobile learning (Cheng, 2014).

Interestingly several authors have sought to investigate Personal Innovativeness in more detail by subjecting data relating to innovativeness to further analysis in order to identify the key dimensions of innovation (see Table 1). This is useful not only in terms of understanding the concept of Personal Innovativeness but also as a means of reducing the data set in order to focus management attention on those aspects that are of greatest importance (Field, 2012). As with much of the research into Personal Innovativeness it is difficult to compare and contrast the results of these studies because they have different theoretical intentions and make use of different methodologies (Roehrich, 2004). However, it is apparent that while three of the four studies listed in Table 1 identify three key dimensions the dimensions themselves are indeed very different. This may very well be due to limited published research as well as the differing intentions of the various studies but it does mean that this is an area of innovation theory that may benefit from further research and, although not the primary aim of the study 
underpinning this paper, this study has generated findings that appear to contribute usefully to knowledge.

\section{TABLE 1 - ABOUT HERE}

A questionnaire was developed based primarily on the 20 point Ettlie and O'Keefe (1982) Innovativeness Scale (see Annex 1), which has been used in several other recent applications (eg Munoz-Doyague and Nieto, 2012; Whetton and Cameron, 2011). The questionnaire was piloted in an on-line format across a range of industry sectors and feedback was used to make a number of subsequent modifications. The poor response rate to the on-line pilot was addressed with a mixed method of data collection being adopted for the main survey. The online approach to data collection was retained for surveying the University Sector but a postal survey was conducted in all the other sectors.

A total of 4,777 questionnaires were posted out to managers working in various industry sectors in the UK and 403 were returned completed which constitutes an overall response rate of $8.4 \%$. The response rate by sector is shown in Table 2. The sample size of 404 gives the findings a $95.0 \%$ level of confidence with a margin of error of $+/-5.0 \%$ (West, 1999). The data was analysed using SPSS 19 and the findings relating to the market for micro-scale anaerobic digestion reported elsewhere (Goodall et al, 2014).

\section{TABLE 2 - ABOUT HERE}

\section{$4 \quad$ Results}

The data generated by the 20 point Ettlie and O'Keefe (1982) Innovativeness Scale is summarised in Table 3. The calculation of a mean makes it possible to rank the statements and identify those that the respondents identify with most and those that they identify with least. Indeed, in the first instance it is apparent that there is a tendency to agree with the majority of the statements which may in itself suggest that as a group the respondents have something of a predisposition to innovate. It is also apparent, that the respondents see themselves as being humorous, willing to speak out in public and willing to try new ideas and approaches. Conversely, it is apparent that as they tend not to set aside resources for risky projects they may be a little risk averse, which might be intuitively against the conventional wisdom regarding innovators, and they do not necessarily use their personal contacts to maneuver themselves into choice work assignments.

Initially, therefore, the data suggests that the respondents are indeed innovative, however, when the Scoring Scale advocated by Whetton and Cameron (2011) (see Annex 1) is applied to the data there is something of a surprise. The overall score for all the respondents is $74 \%$ which suggests that only $50 \%$ of people generally will score below the respondent's which in turn suggests that the respondents are not particularly innovative. Analysis at the Sector Level (see Table 4) appears to provide further evidence to support this contention. While somewhat 
unexpected it is possible that this could be because some of the respondents are employed in sectors which in the UK remain in the public sector where the imperative to innovate is not so strong. Indeed, when this finding is related back to the initial data where many respondents have reported agreement with innovativeness statements it is possible to suggest that for many it is more important to be perceived as innovative rather than actually being innovative and confirms Midgley and Dowling's (1978) view that it is useful to distinguish between propensity to innovative and actual Personal Innovativeness.

The original Whetton and Cameron (2011) Scoring Scale was developed from data provided by students so the scale and subsequent interpretation may not be particularly valid. Although no issues were identified with regard to the Ettlie and O’Keefe (1982) Innovativeness Scale itself the fact that this survey collected data from practicing managers means that a Scoring Scale developed from this data may well be both different to and of greater value than the Whetton and Cameron (2011) Scoring Scale. In the event two alternative Scoring Scales were developed from the current data set and are presented as Tables 5 and 6. Table 5 makes use of the same scores as the original Whetton and Cameron (2011) Scoring Scale and has been produced to allow direct comparison. This Table confirms that there is a difference between the original Whetton and Cameron (2011) Scoring Scale and the new scale developed using the current data set. The second Scoring Scale presented in Table 6 has had the Scores adjusted to focus on the quartiles which are more commonly used reference points (Field, 2012) and as such may serve as more useful review points for researchers who wish to make use of the Ettlie and O'Keefe (1982) Innovativeness Scale in the future. However, when the data from the current study is revisited using the revised Scoring Scales it is apparent that it simply serves to confirm that the respondents are not particularly innovative.

TABLE 3 - ABOUT HERE

TABLE 4 - ABOUT HERE

TABLE 5 - ABOUT HERE

TABLE 6 - ABOUT HERE

\subsection{Dimensions of Innovativeness}

In order to examine the data for key dimensions it was subject to a Principal Component Factor Analysis with Varimax Rotation. Missing data had to be replaced by mean values in order to successfully run the analysis which then converged in 9 iterations. The overall Kaiser-MeyerOlkin (KMO) Measure of Sampling Adequacy of 0.888 indicates that the sampling adequacy is "great" (Field, 2012; Hutcheson and Sonfroniou, 1999) while Bartlett's Test of Sphericity $\left(\mathrm{X}^{2}(190)=2,382.439, \mathrm{p}<.001\right)$ indicates that there are relationships between the variables and that this result is highly significant and that factor analysis is appropriate for use with this data. The output from the Factor Analysis is presented in Table 7 where with an Eigenvalue cut-off of 1.0 it appears that a five factor solution, explaining $56.21 \%$ of the variance in the data, is the optimal solution. Output from similar analyses conducted at the individual sector level lends further support to the five factor solution (Table 
8). The items that load on the same factor are highlighted and an interpretation based on the views of the research team and a number of independent researchers is presented in Table 9 .

\author{
TABLE 7 - ABOUT HERE \\ TABLE 8 - ABOUT HERE \\ TABLE 9 - ABOUT HERE
}

The statements that load on the Factors appear to suggest that there are five dimensions to a manager's Personal Innovativeness: Leadership, Team, Communication, Risk, and Reward. Intuitively, these five dimensions seem entirely appropriate and this then provides valuable insight for managers. A manager engaged in innovation must demonstrate leadership in order to engage those staff for whom they are responsible in the innovation. If they are to engage the talents and skills of the staff in the innovation process they also need to be able to take a team approach to the process. The fact that innovation involves a team and that to maximise the chances of successful innovation the team must work together well then there is a need to communicate efficiently and effectively. Of course, as with any work activity the final outcome cannot be guaranteed and so there is an element of risk involved. However, alongside risk there is also reward and this not only serves to motivate the manager but also to counter the risks. It would appear, therefore that these dimensions have face validity (Denzin, 1978).

The outcome of the factor analysis is interesting not only because of the nature of the dimensions identified but also because of the number and this then provides valuable insight for academic researchers interested in innovation. In the previous studies noted in Table 1 the number of dimensions identified range from one (Hurt et al, 1977) through to four (Goldsmith, 1991) with two studies (Ettlie and O'Keefe, 1982; Gibson and Gibson, 2011) finding the existence of three dimensions. Although the number of studies looking at the dimensions of Personal Innovativeness are small (just five including this study) which makes it impossible to be certain, and the fact that the Gibson and Gibson (2011) study might be construed as contradictory, there is some evidence to suggest that over time the concept of innovativeness has fragmented and that today it is more complex than in the past. In addition to the findings from this study there is some evidence to this effect to be found in the literature where Rhaiem (2012) states that "..the innovation process has become more complex...”. If correct the implications of this trend are important as senior managers would need to ensure that junior managers they appoint to innovate have the skills and aptitude to engage on the five dimensions and / or they need to ensure that staff development is available to promote these characteristics in employees.

\title{
$5 \quad$ Summary and Conclusion
}

Innovation is an essential activity for most businesses if they wish to remain competitive in the early $21^{\text {st }}$ century. As a consequence, the predisposition to innovate or Personal Innovativeness is a desirable characteristic of employees and especially managers. As a consequence, this study collected information regarding Personal Innovativeness from 403 
managers employed across a wide range of business sectors using the 20 point Ettlie and O’Keefe (1982) Innovativeness Scale.

The research has a number of limitations that serve as caveats regarding the findings. The first is that Whetton and Cameron's (2011) Scoring Scale for Ettlie and O'Keefe (1982) Innovativeness Scale, was developed with students and not practicing managers and the different samples may account for at least some of the differences in the findings. Second, over time and with applications in different domains it has been necessary to adapt the wording of Ettlie and O'Keefe's (1982) original scale (eg "wit" was changed to "sense of humour" and "manager" was changed to "governors and / or LEA" for use in the school sector) and this also could account for some of the differences in the findings. Third, the issue of concept and construct diversity, originally identified by Ettlie and O'Keefe (1982), remains applicable today and this makes relating the results of this study to the other studies reporting on innovativeness dimensions challenging. Finally, while the findings of this survey and factor analysis are statistically significant some of the subsequent observations are, in essence, made using a meta-analysis of the findings arising from several other studies of innovativeness dimensions. However, the number of such studies is very small and so these findings must be treated with caution. For the reasons just outlined it is apparent that the findings of this study are not conclusive, however, they are based on a survey of a fairly large number of managers and the results are statistically significant so it appears that the insight arising from the findings make a useful contribution to the subject area of innovation in general and the debate about Personal Innovativeness in particular.

A review of the initial descriptive data suggests that the respondents are indeed well disposed to innovation but application of Whetton and Cameron's (2011) Scoring Scale reveals that they are actually no more innovative than $50 \%$ of the population. Development and application of an alternative Scoring Scale based on the data provided by the practicing managers who responded to this survey only serves to further confirm the limited innovativeness of the respondents. Of much more interest and theoretical importance, however, are the results of a factor analysis of the data which sort to identify the key dimensions of Personal Innovativeness. Not only did this reveal the existence of five key dimensions relating to Leadership, Team, Communication, Risk, and Reward but it also suggests that over time innovativeness has fragmented and is becoming more complex.

The findings of the study have important practical implications for managers who will be expected to engage in innovation. In the first instance, it is intuitively appealing to appoint managers with relatively high levels of Personal Innovativeness to roles where they will be expected to innovate and that with some minor grammatical changes to contextualise and update it the Ettlie and O'Keefe's (1982) Innovativeness Scale remains a valid measure of Personal Innovativeness that may be usefully employed as a diagnostic tool in the recruitment process for managers. It would also appear that the Ettlie and O’Keefe (1982) Innovativeness Scale, and especially the data arising from its application, can be used to inform the education and training of managers. The fact that in the contemporary work situation Personal Innovativeness has five key dimensions relating to Leadership, Team, Communication, Risk, and Reward will allow managers to focus their attention and efforts and look to develop these attributes in their employees in order to facilitate innovation. The findings from an application of the Ettlie and O'Keefe's (1982) Innovativeness Scale might also be used to facilitate innovation through the design of reward packages to encourage the recruitment of 
employees with high levels of Personal Innovativeness and, hence, have a role to play in the allocation of resources.

Finally, while this study has provided useful insight into Personal Innovativeness it has also established a need for further research and provided some direction and focus for future studies in the area. The fact that the findings of this study must be treated as provisional means that there is a need for further research to verify the findings while it is also evident that the development of an Personal Innovativeness scale designed specifically for use in the various specific sectors may well provide results that have higher predictive power than the Ettlie and O’Keefe’s (1982) Innovativeness Scale.

\section{Acknowledgements}

The authors would like to thank Tuffa UK Ltd., the Technology Strategy Board and DEFRA for funding this work; everyone who responded to the survey; $\mathrm{Mr}$ and Mrs R. Browning for assisting with the distribution of the postal questionnaire; and Dr Paul Custance and Miss Rachel Walley for their assistance with the factor interpretation. 


\section{References}

Agarwal, R. and Prasad, J. (1998) 'A conceptual and operational definition of personal innovativeness in the domain of information technology', Information Systems Research, Vol. No. 9, pp.204-215.

Augusto, M.G.; Lisboa, J.V.; and Yasin, M.M. (2014) 'The mediating role of innovation on strategic orientation and performance', International Journal of Business Innovation and Research, Vol. 8, No. 3, pp.282-299.

Baumgartner, H. and Steenkamp, J-B.E.M. (1996) 'Exploratory consumer buying behaviour: conceptualization and measurement', International Journal of Research in Marketing, Vol. 3, No. 2, pp.121-37.

Burdon, S.; Al-Kilidar, H.; and Mooney, G. (2013) ‘Evaluating an organisation’s cultural readiness for innovation', International Journal of Business Innovation and Research, Vol. 7, No. 5, pp.572-589.

Cheng, Y-M. (2014) 'Exploring the intention to use mobile learning: the moderating role of personal innovativeness’, Journal of Systems and Information Technology, Vol. 16, No. 1, pp.40-61.

Denzin, N.K. (1978) The Research Act, $2^{\text {nd }}$ edition, McGraw-Hill, New York.

Dershin, H. (2010) 'A framework for managing innovation', International Journal of Business Innovation and Research, Vol. 4, No. 6, pp.598-613.

Dubey, R.; Sonwaney, V.; Aital, P.; Venkatesh, V.G.; and Ali, S.S. (2015) 'Antecedents of innovation and contextual relationship', International Journal of Business Innovation and Research, Vol. 9, No. 1, pp.1-14.

Erekson, O.H.; Gorman, R.F.; and Molloy, L. (2008) 'Innovations in environmental performance: the importance of financial performance and management quality', International Journal of Business Innovation and Research, Vol. 2, No. 4, pp.331-353.

Ettlie, J.O. and O’Keefe, R.D. (1982) 'Innovative Attitudes, Values, and Intentions in Organizations’, Journal of Management Studies, Vol. 19, No. 2, pp.163-182.

Fagan, M.; Kilmon, C.; and Pandey, V. (2012) 'Exploring the adoption of a virtual reality simulation: the role of perceived ease of use, perceived usefulness and personal innovativeness', Campus-Wide Information Systems, Vol. 29, No. 2, pp.117-127.

Field, A. (2012) Discovering Statistics Using SPSS, $3^{\text {rd }}$ edition, Sage Publications Ltd, London.

Gibson, L.G. and Gibson, R.A. (2011) 'Predictors of entrepreneurial innovation attitude: implications for arts and business pedagogy’, proceedings of the United States Association 
for Small Business and Entrepreneurship Conference, Hilton Head Island, South Carolina, pp.1007-1020. [online] http://proceedings.usasbe.org/proceedingsearch.php (Accessed 26 April 2014).

Goldsmith, R.E. (1991) 'The validity of a scale to measure global innovativeness', The Journal of Applied Business Research, Vol. 7, No. 2, pp.89-97.

Goldsmith, R.E.; Freiden, J.B.; and Eastman, J.K. (1995) 'The generality / specificity issue in consumer innovativeness research’, Technovation, Vol. 15, No. 10, pp.601-13.

Goldsmith, R.E. and Hofacker, C.F. (1991) 'Measuring consumer innovativeness', Journal of the Academy of Marketing Science, Vol. 19, No. 3, pp.209-21.

Goodall, S.; Walley, K.; Humphries, A.; Huntington,; White, D.; Asson, T. and Thelwell, S. (2014) 'Improving the efficiency and sustainability of food supply chains: the market potential for micro-scale anaerobic digestion in the UK'. Paper presented at WICaNeM 2014: Sustainability and Innovation in Chain and Networks, $4^{\text {th }}-6^{\text {th }}$ June, Capri, Italy.

Gounaris, S.P. and Koritos, C.D. (2008) 'Using the extended innovation attributes framework and consumer personal characteristics as predictors of internet banking adoption', Journal of Financial Services Marketing, Vol. 13, No. 1, pp.39-51.

Hage, J. and Dewar, R. (1973) 'Elite values versus organizational structure in predicting innovation’. Administrative Science Quarterly, Vol. 18, No. 3, pp.279-290.

Hidayanto, A.N.; Hidayat, L.S.; Sandhyaduhita, P.I.; and Handayani, P.W. (2015) 'Examining the relationship of payment system characteristics and behavioural intention in epayment adoption: a case of Indonesia', International Journal of Business Information Systems, Vol. 19, No. 1, pp.58-86.

Hirschman, E.C. (1980) 'Innovativeness, novelty-seeking, and consumer creativity', Journal of Consumer Research, Vol. 7, No. 3, pp.283-295.

Hormiga, E.; Hancock, C.; and Valls-Pasola, J. (2013) 'The relationship between employee propensity to innovate and their decision to create a company’, Management Decision, Vol. 51, No. 5, pp.938-953.

Hurt, H.T.; Joseph, K.; and Cook, C.D. (1977) 'Scales for the measurement of innovativeness’, Human Communication Research, Vol. 4, No. 1, pp.58-65.

Hutcheson, G. and Sonfroniou, N. (1999) The Multivariate Social Scientist, Sage Publications Ltd, London.

Im, S.; Bayus, B.L.; and Mason, C.H. (2003) 'An empirical study of innate consumer innovativeness, personal characteristics, and new product adoption behaviour', Journal of the Academy of Marketing Science, Vol. 31, No. 1, pp.61-73. 
Jackson, D.N. (1976) Manual of the Jackson Personality Inventory, Research Psychologists Press, Goshen, New York.

Jackson, J.D.; Yi, M.Y. and Park, J.S. (2013) 'An empirical test of three mediation models for the relationship between personal innovativeness and user acceptance of technology', Information \& Management, Vol. 50, No. 4, pp.154-161.

Jansson, J. (2011), 'Consumer eco-innovation adoption: assessing attitudinal factors and perceived product characteristics’, Business Strategy and the Environment, Vol. 20, No. 3, pp.192-210.

Kirton, M.J. (1976) 'Adaptors and innovators: a description and measure', Journal of Applied Psychology, Vol. 61, No. 5, pp.622-629.

Kocak, C. and Onen, A.S. (2012) 'Analysis on reflective thinking tendencies of student teachers according to their personal innovativeness', Hacettepe Universitesi Egitim Fakultesi Dergisi-Hacettepe University Journal of Education, Special Issue Vol. 2, pp.46-54.

Kourouthanassis, P.E.; Giaglis, G.M.; Karaiskos, D.; and Zamani, E. (2014) 'Adoption behaviour differences for mobile data services: m-internet vs. m-portals’, International Journal of Mobile Communications, Vol. 12, No. 3, pp.207-228.

Leavitt, C. and Walton, J.R. (1975) 'Development of a scale for innovativeness', in M.J. Schlinger (Ed.), Advances in Consumer Research, Vol. 2, Association for Consumer Research: Ann Arbor, pp.545-554.

Lin, C.A. (2006) 'Predicting webcasting adoption via personal innovativeness and perceived utilities’, Journal of Advertising Research, Vol. 46, No. 2, pp.228-238.

Lu, J. (2014) 'Are personal innovativeness and social influence critical to continue with mobile commerce?’ Internet Research, Vol. 34, No. 2, pp.134-159.

Midgley D.F. and Dowling, G.R. (1978) 'Innovativeness: the concept and its measurement', Journal of Consumer Research, Vol. 4, No. 4, pp.229-242.

Midgley D.F. and Dowling, G.R. (1993) 'A longitudinal study of product form innovation: the interaction between predispositions and social messages', Journal of Consumer Research, Vol. 19, No. 4, pp.611-625.

Moore, G.A. (1999) Crossing the chasm, $2^{\text {nd }}$ edition, Harper Collins, New York.

Munoz-Doyague, M.F. and Nieto, M. (2012) 'Individual creativity performance and the quality of interpersonal relationships’, Industrial Management \& Data Systems, Vol. 112, No. 1, pp.125-145.

Nabseth, L. and Ray, G.F. (1974) The diffusion of new industrial processes, Cambridge University Press, London. 
Ostlund, L.E. (1974) 'Perceived innovation attributes as predictors of innovativeness', Journal of Consumer Research, Vol. 1, No. 2, pp.23-29.

Pallister, J.G. and Foxall, G. (1998) 'Psychometric properties of the Hurt-Joseph-Cook scales for the measurement of innovativeness’, Technovation, Vol. 18, No. 11, pp.663-675.

Pentina, I.; Pullins, E.B.; and Wilkinson, J.W. (2014) 'Comparing drivers of social media marketing adoption by salespeople in Australia and the USA: a pilot study', International Journal of Information Systems and Management, Vol. 1, No. 1 / 2, pp.146-165.

Priyadharshini, S.K.; Kamalanabhan, T.J.; and Madhumathi, R. (2015) 'Human resource management and firm performance', International Journal of Business Innovation and Research, Vol. 9, No. 2, pp.229-251.

Raju, P.S. (1980) Optimum stimulation level: its relationship to personality, demographics and exploratory behaviour, Journal of Consumer Research, Vol. 7, No. 3, pp.272-82.

Rhaiem, M. (2012) 'Innovate or perish: success factors and sources of failure', Journal of International Business and Economics, Vol. 12, No. 3, pp.102-122.

Roca, J.C.; Machado, J.J.G.; and De La Vega, J.J. (2010) 'Personal innovativeness, security and privacy as determinants of e-trading adoption', International Journal of Electronic Finance, Vol. 4, No. 3, pp.269-286.

Roehrich, G. (2004), 'Consumer innovativeness: concepts and measurement', Journal of Business Research, Vol. 57, No. 6, pp.671-677.

Rogers, E.M. (1995) Diffusion of Innovations, $4^{\text {th }}$ edition, The Free Press, New York.

Rokeach, M. (1967) 'Attitude change and behavioural change’, Public Opinion Quarterly, Vol. 30, No. 4, pp.529-550.

Rothwell, R. (1994) 'Towards the fifth-generation innovation process', International Marketing Review, Vol. 11, No. 1, pp.7-31.

Schumpeter, J.A. (1943) Capitalism, Socialism, and Democracy, $6^{\text {th }}$ edition, Routledge, London.

Steenkamp, J-B.E.M.; Hofstede, F.; and Wedel, M. (1999) 'A cross-national investigation into the individual and national cultural antecedents of consumer innovativeness', Journal of Marketing, Vol. 63, No. 2, pp.55-69.

Tan, W.K and Sie, M.S. (2015) 'The impact of personal innovativeness on product aesthetics and self-connection with brand: a case study of mobile phone users', Behaviour \& Information Technology, Vol. 34, No. 3, pp.316-325. 
Tellis, G.J.; Yin, E.; and Bell, S. (2009) 'Global consumer innovativeness: cross-country differences and demographic commonalities’, Journal of International Marketing, Vol. 17, No. 2, pp.1-22.

Thakur, R. and Srivastava, M. (2015) 'A study on the impact of consumer risk perception and innovativeness on online shopping in India', International Journal of Retail \& Distribution Management, Vol. 43, No. 2, pp.148-166.

Trott, P. (2012) Innovation Management, $5^{\text {th }}$ edition, Financial Times Prentice-Hall, Pearson, Harlow, Essex.

Venkatraman, M.P. (1991) 'The impact of innovativeness and innovation type on adoption', Journal of Retailing, Vol. 67, No. 1, pp.51-67.

West, C. (1999), Marketing Research, MacMillan Business Masters. MacMillan Press Ltd, Basingstoke, Hampshire.

Whetton, D.A. and Cameron, K.S. (2011) Developing Management Skills, $8^{\text {th }}$ edition, Pearson, New Jersey.

Yang, K.H.; Lee, S.M.; and Lee, S-G. (2007) 'Adoption of information and communication technology: impact of technology types, organization resources and management style', Industrial Management \& Data Systems, Vol. 107, No. 9, pp.1257-1275.

Yi, M.Y.; Fiedler, K.D.; and Park, J.S. (2006) 'Understanding the role of individual innovativeness in the acceptance of IT-based innovations: comparative analyses of models and measures', Decision Sciences, Vol. 37, No. 3, pp.393-426. 


\section{Annex 1 - The Original Ettlie and O’Keefe 20-item Innovation Scale}

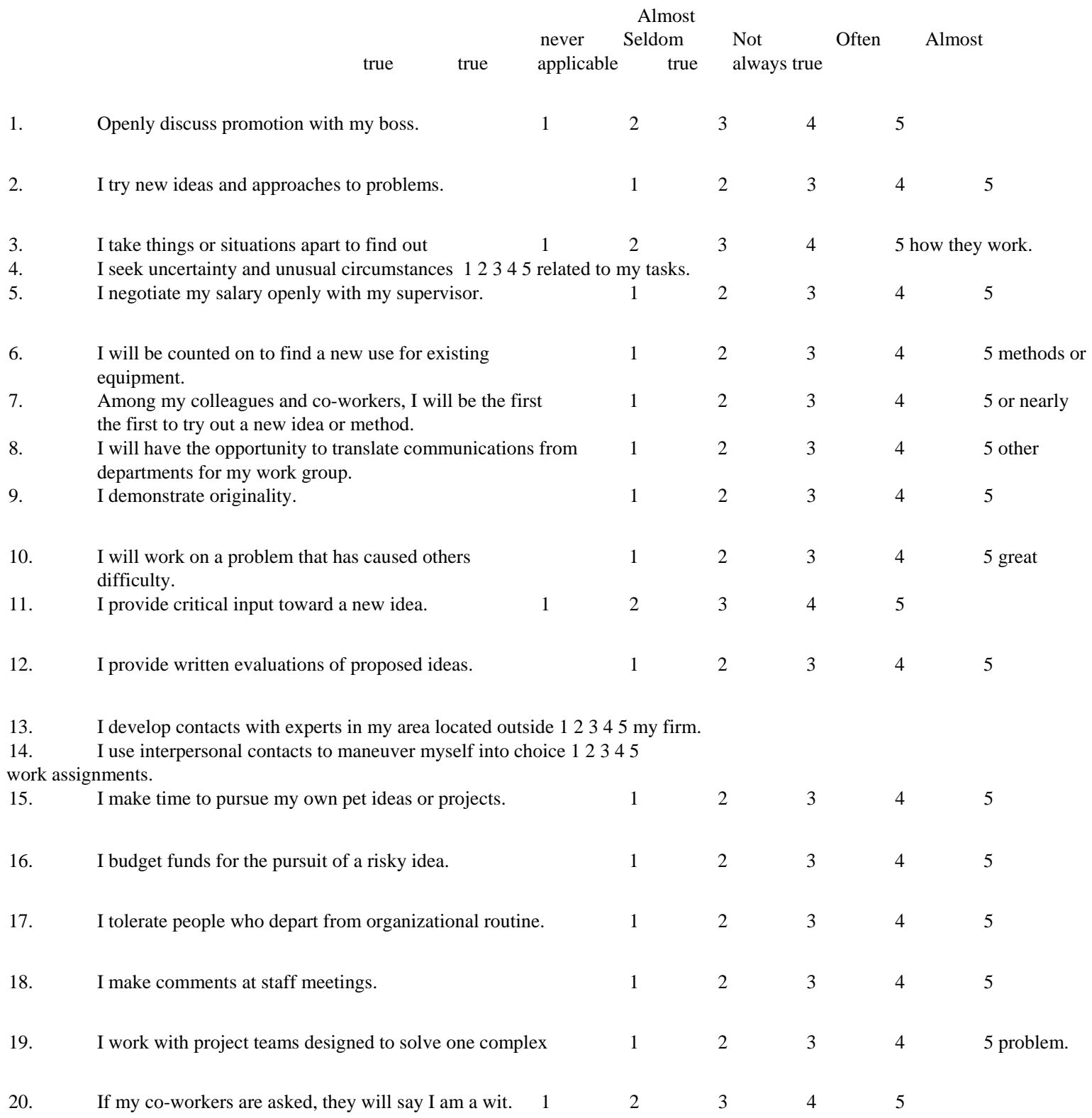

Source: Ettlie and OKeefe (1982)

\section{Scoring Key}

To compute your score on the Innovative Attitude Scale, simply add up the numbers for your responses to the twenty questions. Then compare your total score to the following norm group. Note that the percentile indicates the percent of the people who are expected to score below you.

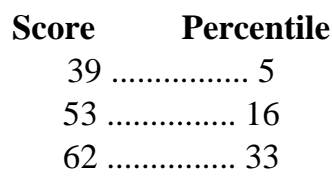




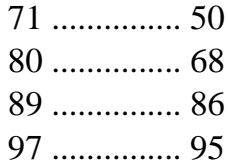

Source: Whetton and Cameron (2011)

Table 1 - Key Dimensions of Innovation

\begin{tabular}{|l|l|l|l|}
\hline Hurt et al (1977)1 & \multicolumn{1}{|c|}{$\begin{array}{c}\text { Ettlie and } \\
\text { O'Keefe (1982) }\end{array}$} & \multicolumn{1}{|c|}{$\begin{array}{c}\text { Goldsmith } \\
\text { (1991) }\end{array}$} & \multicolumn{1}{|c|}{ Gibson and Gibson (2011) } \\
\hline i innovativeness & $\begin{array}{l}\text { i. innovator ii. } \\
\text { preserver of the } \\
\text { status quo (Anti- } \\
\text { innovator) iii. } \\
\text { Unchallenged }\end{array}$ & $\begin{array}{l}\text { i. willingness } \\
\text { to try ii } \\
\text { creative } \\
\text { original iii } \\
\text { opinion } \\
\text { leader iv } \\
\text { ambiguities } \\
\text { and problems }\end{array}$ & $\begin{array}{l}\text { i feelings that change is } \\
\text { energizing and exciting ii } \\
\text { feelings that new methods and } \\
\text { procedures should be attempted } \\
\text { iii beliefs that there exist new } \\
\text { and unusual paths to achieve } \\
\text { the final goal and success }\end{array}$ \\
& &
\end{tabular}

${ }^{1}$ This study did identify two factors but the authors acknowledge that the bi-dimensionality of this result was an artefact of the directionality of the wording of items, rather than the content of the items, and in the end concluded that innovativeness was uni-dimensional.

Table 2: Response by Sector

\begin{tabular}{lccc}
\hline Sector & Total Sent & Total Returned & Response Rate \\
\hline Hotel & 2000 & 173 & $8.6 \%$ \\
School & 2000 & 139 & $6.9 \%$ \\
Prisons & 137 & 23 & $16.7 \%$ \\
Golf Courses & 152 & 13 & $8.6 \%$ \\
Food Processing & 221 & 27 & $12.2 \%$ \\
Universities & 115 & 8 & $7.8 \%$ \\
Hospitals & 152 & 21 & $13.1 \%$ \\
& & & $8.4 \%$
\end{tabular}

Table 3 - Ranked Responses

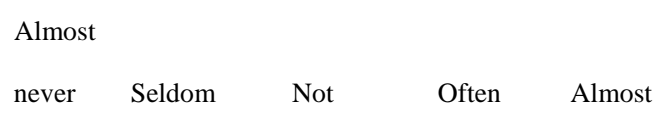


true true applicable true always true Mean

1.If my co-workers are asked, they will say I have a

5

15

185

133

4.16

sense of humour.

2.I speak out in staff meetings.

great difficulty

other departments for my work group.

10.I openly discuss with my how to get ahead with my

Line management.

11.Among my colleagues and co-workers, I will be the first or nearly the first to try out a new idea or method.

12.I take things or situations apart to find out how they work.

13.I can be counted on to find a new use for existing methods or equipment.

14.I negotiate my salary openly with senior management. 
Table 4 - Innovativeness by Sector

$\begin{array}{lrr} & \text { N } & \text { Mean } \\ \text { Hotels } & 173 & 74 \% \\ \text { Schools } & 139 & 73 \% \\ \text { Universities } & 8 & 70 \% \\ \text { Food Processors } & 27 & 75 \% \\ \text { Hospitals } & 21 & 73 \% \\ \text { Prisons } & 23 & 71 \% \\ \text { Golf Courses } & 13 & 78 \%\end{array}$

Table 5 Revised Scoring Scale Using Original Scores

Percentile Score

Percentile from this study

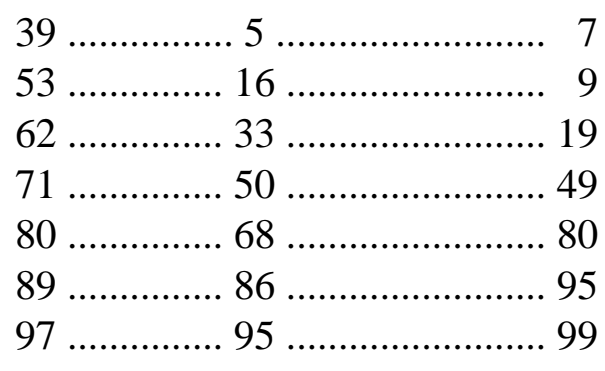

Table 6 Revised Scoring Scale Using Quartiles

Percentile Score from this study
$65 \ldots \ldots \ldots \ldots \ldots \ldots . . .25 \%$
$71 \ldots \ldots \ldots \ldots \ldots . .50 \%$




\begin{tabular}{|c|c|c|c|c|c|}
\hline \multirow[b]{2}{*}{ Item } & \multicolumn{5}{|c|}{ Component } \\
\hline & 1 & 2 & 3 & 4 & 5 \\
\hline $\begin{array}{l}\text { 1. I openly discuss how to get ahead with my } \\
\text { line management. }\end{array}$ & -.030 & .015 & .474 & .571 & .372 \\
\hline 2. I try new ideas and approaches to problems. & .246 & -.025 & .246 & .734 & -.045 \\
\hline $\begin{array}{l}\text { 3. I take things or situations apart to find out } \\
\text { how they work. }\end{array}$ & .240 & .173 & -.040 & .731 & .135 \\
\hline $\begin{array}{l}\text { 4. I welcome uncertainty and unusual } \\
\text { circumstances related to my tasks. }\end{array}$ & .235 & .351 & -.038 & .546 & -.068 \\
\hline $\begin{array}{l}\text { 5. I negotiate my salary openly with senior } \\
\text { management. }\end{array}$ & .133 & .059 & .050 & & .790 \\
\hline $\begin{array}{l}\text { 6. I can be counted on to find a new use for } \\
\text { existing methods or equipment. }\end{array}$ & .574 & .023 & .052 & .298 & .280 \\
\hline $\begin{array}{l}\text { 7.Among my colleagues and co-workers, I will } \\
\text { be the first or nearly the first to try out a new } \\
\text { idea or method. }\end{array}$ & .729 & .124 & .038 & .265 & .042 \\
\hline $\begin{array}{l}\text { 8.I take the opportunity to translate } \\
\text { communications from other departments for } \\
\text { my work group. }\end{array}$ & .456 & .145 & .436 & .107 & -.032 \\
\hline 9.1 demonstrate originality. & & .240 & .163 & .159 & -.016 \\
\hline $\begin{array}{l}\text { 10.I will work on a problem that has caused } \\
\text { others great difficulty. }\end{array}$ & .723 & .111 & .268 & .101 & .063 \\
\hline & & $\begin{array}{l}.107 \\
.234\end{array}$ & $\begin{array}{l}.266 \\
.309\end{array}$ & $\begin{array}{l}.147 \\
.132\end{array}$ & \\
\hline 11. I provide critical input toward a new solution. & .696 & .145 & .391 & .066 & .125 \\
\hline $\begin{array}{l}\text { 12. I provide written evaluations of proposed } \\
\text { ideas. }\end{array}$ & .326 & & .101 & .127 & .112 \\
\hline $\begin{array}{l}\text { 13. I develop contacts with experts outside } \\
\text { my organisation. }\end{array}$ & & & .022 & -.108 & .357 \\
\hline $\begin{array}{l}\text { 14. I use personal contacts to maneuver } \\
\text { myself into choice work assignments. }\end{array}$ & .447 & & .113 & -.133 & .366 \\
\hline $\begin{array}{l}\text { 15. I make time to pursue my own pet ideas } \\
\text { or projects. }\end{array}$ & & & .185 & .160 & .159 \\
\hline $\begin{array}{l}\text { 16. I set aside resources for the pursuit of a } \\
\text { risky project. }\end{array}$ & .243 & .700 & & .118 & -.048 \\
\hline $\begin{array}{l}\text { 17. I tolerate people who depart from } \\
\text { organizational routine. }\end{array}$ & & & & .083 & -.219 \\
\hline & .091 & .719 & & & \\
\hline
\end{tabular}




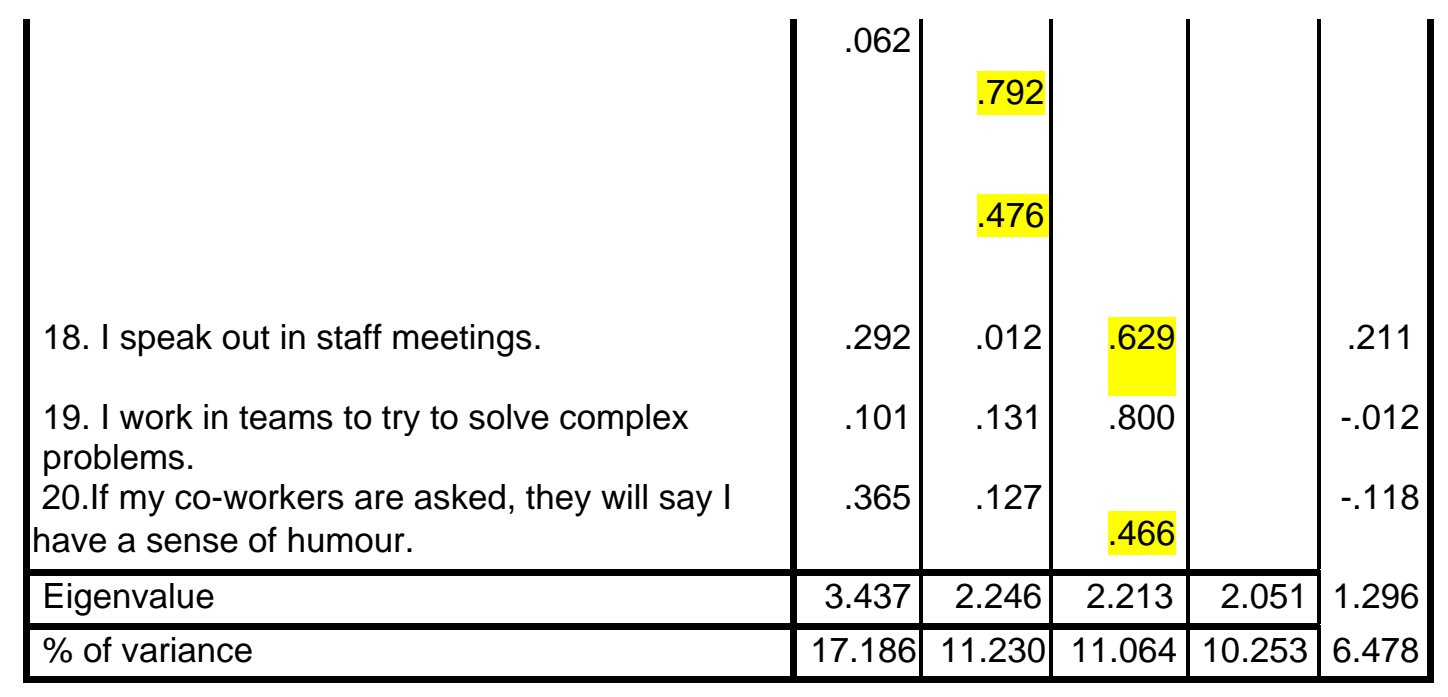

KMO and Bartlett's Test

Kaiser-Meyer-Olkin Measure of Sampling Adequacy.

Approx. Chi-Square

2382.439

Bartlett's Test of Sphericity

df

Sig.

.000

Table 8 - Number of Factors in Sector Data

Hotels

No. of Factors

Schools

5

Universities $^{1}$

Food Processors

Hospitals

Prisons

Golf Courses

${ }^{1}$ Insufficient data to compute Factors.

5

$-$

6

7

5

5

Table 9 Factor Interpretation

Factor 1 Leadership dimension

Factor 2 Team dimension

Factor 3 Communication dimension

Factor 4 Risk dimension

Factor 5 Reward dimension 
